\title{
Cellular levels of thymosin immunoreactive peptides are linked to proliferative events: Evidence for a nuclear site of action
}

\author{
(thymosin $\alpha_{1} /$ prothymosin $\alpha /$ immunoelectron microscopy/nuclear peptide)
}

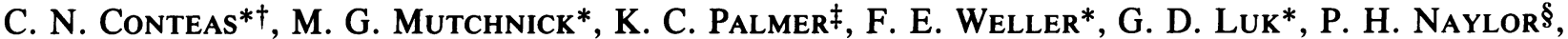 \\ M. R. Erdos $\$$, A. L. Goldstein $\$$, C. Panneerselvam $₫$, and B. L. Horecker
}

Departments of *Medicine and $¥$ Pathology, Wayne State University School of Medicine, Detroit, MI 48201; §Department of Biochemistry and Molecular
Biology, The George Washington University School of Medicine, Washington, DC 20037; and "Department of Biochemistry, Cornell University Medical College, New York, NY 10021

Contributed by B. L. Horecker, February 20, 1990

\begin{abstract}
Thymosin $\alpha_{1}\left(T \alpha_{1}\right)$, the N-terminal 28-amino acid fragment of prothymosin $\alpha(\operatorname{ProT} \alpha)$, and ProT $\alpha$, although originally isolated from whole thymus extracts, are also present in nonthymic cells and tissues. We used an ELISA with an antibody raised against $T \alpha_{1}$ to investigate the relationship between intracellular levels of thymosin immunoreactive peptide(s) (TIP) and cell proliferation in a rat small intestinal IEC-6 cell line. Increasing TIP levels were observed during cell proliferation, which decreased when proliferation was halted by cellular contact inhibition. Serum feeding of cells previously rendered quiescent by serum starvation resulted in a significant increase in TIP within $1 \mathrm{hr}$. Conversely, serum starvation decreased TIP levels within $1 \mathrm{hr}$. Peak TIP levels appeared after $3 \mathrm{hr}$ of serum incubation, while maximum $\left[{ }^{3} \mathrm{H}\right.$ ]thymidine incorporation was noted after $9 \mathrm{hr}$, suggesting maximum TIP concentrations in the $G_{1}$ phase of the proliferative cycle. Immunoelectron microscopy demonstrated an association of TIP with condensed nuclear chromatin. These results support a relation of intracellular TIP levels to IEC-6 cell proliferation and also a nuclear site of action. HPLC analysis of cellular homogenates from proliferating IEC-6 cells revealed a peak of immune reactivity that elutes in the position of $\mathrm{T} \alpha_{1}$.
\end{abstract}

Prothymosin $\alpha$ (ProT $\alpha)$ and thymosin $\alpha_{1}\left(\mathrm{~T} \alpha_{1}\right)$ are polypeptides originally isolated from thymus or extracts of thymic tissue and having molecular weights of 12,600 and 3108 , respectively. The sequence of $\mathrm{T} \alpha_{1}$ (1) (28 amino acids) is identical to the $\mathrm{N}$ terminus of ProT $\alpha$, from which it is considered to be derived (2). Thymosin immunoreactive peptide(s) (TIP) has been localized by immunochemical staining techniques in the cytoplasm of medullary thymic epithelial cells and in cultured thymus epithelial cells (3). TIP has also been reported to be secreted by thymic epithelial cells in culture, consistent with a potential role in thymic differentiation (4). Most recently, secretion and synthesis of ProT $\alpha$ has been reported in different subpopulations of calf and rat thymocytes (5).

The presence of TIP in other nonthymic tissues (6), however, and a structural similarity between ProT $\alpha$ and nuclear proteins (7) have raised the possibility that these polypeptides may also participate in intracellular events. A possible relation of ProT $\alpha$ to cell proliferation was suggested by Eschenfeldt and Berger (8), who observed a significant increase in ProT $\alpha$ mRNA in an NIH 3T3 cell line within the first $12 \mathrm{hr}$ after initiation of proliferation by serum refeeding and a decrease when proliferative quiescence was induced by serum starvation. In addition, covalent binding of ProT $\alpha$ to a cytoplasmic mRNA was described in mouse ascites carcinoma cells (9) and higher levels of human ProT $\alpha$ mRNA were

The publication costs of this article were defrayed in part by page charge payment. This article must therefore be hereby marked "advertisement" in accordance with 18 U.S.C. $\$ 1734$ solely to indicate this fact. found in proliferating immature $\mathrm{T}$ lymphocytes from patients with acute lymphocytic leukemia than in lymphocytes from healthy controls (10). Oates et al. (11) have described a $\mathrm{T} \alpha_{1}$-induced growth factor-like effect on cell proliferation in the breast carcinoma cell line MCF-7, suggesting a potential autocrine growth factor activity.

With a polyvalent antiserum for $\mathrm{T} \alpha_{1}$ that cross-reacts with ProT $\alpha$, TIP was detected in the mucosa of the rat small intestine and in a rat small intestinal crypt cell line (IEC-6) (12). A demonstrable increase in TIP was seen in these cells during the proliferative phase as compared to cells in quiescence.

Utilizing an ELISA with an antibody raised against $\mathrm{T} \alpha_{1}$, we report here the relationship of TIP to cell proliferation in the IEC- 6 cell line. This line retains a structural similarity to the undifferentiated cells of the small intestinal crypt (13). IEC-6 cells proliferate in response to several growth factors and hormones considered trophic for the growth of the small intestinal mucosa $(14,15)$. The proliferation of these cells is inhibited by cellular contact and by fractions isolated from small intestinal villus cell homogenates (15). We find that TIP is present in IEC-6 cells with negligible levels of crossreacting materials present in the medium. Total intracellular concentrations of TIP are increased when IEC-6 cell proliferation is promoted by serum feeding. Furthermore, immunoelectron microscopy revealed a tendency for localization of TIP in the nuclei of the proliferating cells.

\section{MATERIALS AND METHODS}

IEC-6 Cell Line. IEC-6 cells (a generous gift from John Adams, Orthopedic Hospital, University of Southern California, Los Angeles) from passage 11 were grown in $75-\mathrm{cm}^{2}$ culture flasks (GIBCO) in the presence of Dulbecco's modified Eagles' medium (DMEM) with 5.0\% fetal calf serum ( $\mathrm{pH}$ 7.3) (FCS; GIBCO). This is a continuous cultured cell line originally isolated from the small intestine of germ-free neonatal Sprague-Dawley rats by Quaroni et al. (13), who have characterized this cell line in detail.

Experimental Procedures. IEC-6 cells $\left(1.5 \times 10^{6}\right.$ cells $)$ harvested from actively proliferating cultures grown in $5.0 \%$ FCS were seeded into $75-\mathrm{cm}^{2}$ flasks (Costar) and grown under the conditions outlined. Harvesting of the cells was performed by exposure to a trypsin/EDTA solution $(0.5 \%$ trypsin/5.3 mM EDTA; GIBCO) for $11 \mathrm{~min}$. Culture media obtained immediately prior to harvesting were saved for TIP measurements. The harvested cells were washed with cold

Abbreviations: T $\alpha_{1}$, thymosin $\alpha_{1}$; ProT $\alpha$, prothymosin $\alpha$; TIP, thymosin immunoreactive peptide(s).

tTo whom reprint requests should be addressed at: Section of Gastroenterology, Hutzel Hospital, 4707 Saint Antoine, Detroit, MI 48201. 
phosphate-buffered saline (PBS) after centrifugation for 6 min at $1200 \times g$ at $4^{\circ} \mathrm{C}$ and counted with a hemocytometer. After a final washing in PBS, the cells were resuspended in $1.0 \mathrm{ml}$ of PBS in Eppendorf tubes. These tubes were then frozen in liquid nitrogen and thawed in water at room temperature three times. The suspension was checked microscopically for completeness of lysis and centrifuged in a Beckman Microfuge for $30 \mathrm{~min}$ at $15,000 \times \mathrm{g}$. The supernatants were aspirated from the pelleted debris and maintained at $-60^{\circ} \mathrm{C}$ for later analysis. TIP concentrations were measured by ELISA (16) and expressed as T $\alpha_{1}$ picoequivalents (peq) per $10^{6}$ IEC- 6 cells. The polyvalent antibody to $\mathrm{T} \alpha_{1}$ used in the ELISA shows no significant cross-reactivity with common serum proteins and other thymus-derived peptides such as thymic humoral factor, facteur thymique serique, or thymopoietin $(16,17)$. ProT $\alpha$ at concentrations up to 500 $\mathrm{ng} / \mathrm{ml}$ does not interfere with $\mathrm{T} \alpha_{1}$ measurements in the ELISA (F.E.W. and M.G.M., unpublished data).

RIA for T $\alpha_{1}$ and ProT $\alpha$ in HPLC Fractions. T $\alpha_{1}$ and ProT $\alpha$ (18) concentrations in the HPLC fractions collected were measured with a modification (19) of the original T $\alpha_{1}$ RIA

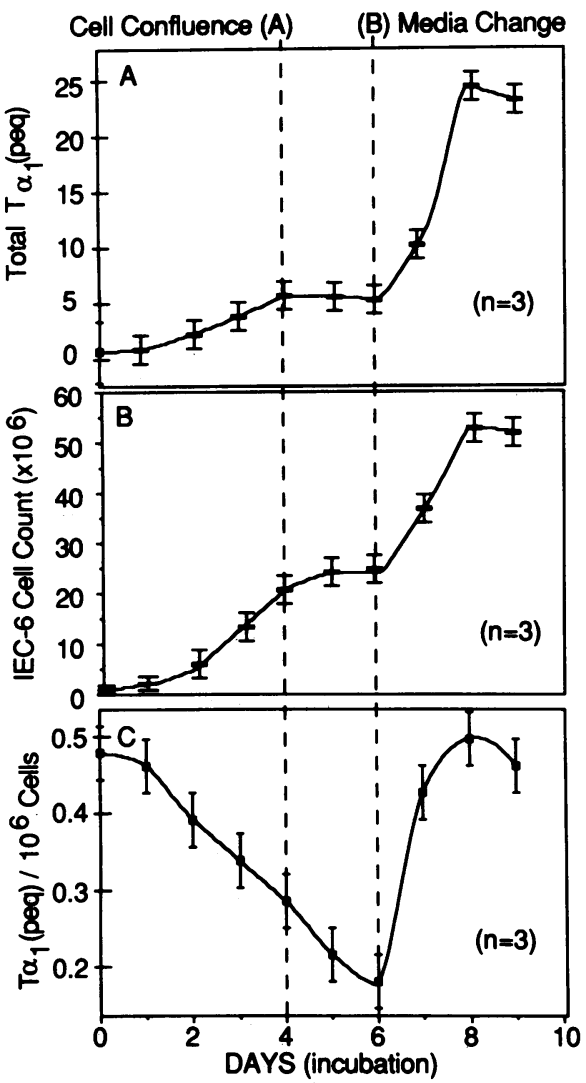

FIG. 1. Correlation of TIP levels and cell proliferation in a 9-day culture system. IEC- 6 cells $\left(1.5 \times 10^{6}\right.$ cells $)$ were seeded into parallel flasks and grown in DMEM/5\% FCS. After visual cell confluence (day 4) and an absence of significant cell proliferation over the ensuing $48 \mathrm{hr}$, the medium was replaced on day 6 with fresh DMEM/5\% FCS (refeeding) and the cultures were maintained until no evidence of further cell proliferation was seen (day 9). Cells were harvested at 24-hr intervals over the 9-day culture and the supernatants of cell lysates were measured for TIP. $(A)$ Increasing total TIP is shown with time. $(B)$ Growth curve of the IEC-6 cells. Note the quiescence between days 4 and 6 with subsequent resumption of proliferation with addition of fresh medium on day $6 .(C)$ Change in cellular TIP over the 9-day incubation period. The decrease in cellular TIP seen during the first 4 days reflects the decreasing ratio of absolute number of proliferating cells to the absolute number of confluent, nonproliferating cells (20). Thus, while there are more cells present by day 4 , proportionately fewer are replicating. TIP values are expressed as mean peq of $T \alpha_{1} \pm$ SD.
(17). The HPLC fractions from the IEC-6 cell extracts were assayed in duplicate.

Statistics. Data are presented as means \pm SD and comparisons were made by Student's $t$ test.

\section{RESULTS}

Correlation of TIP with Cell Proliferation. Proliferation of IEC-6 cells promoted by DMEM/5\% FCS was associated with a concomitant increase in total TIP (Fig. $1 A$ and $B$ ), which increased with time until the entire culture reached confluence on day 4. Cellular TIP (per $10^{6}$ cells) decreased continuously with time as the ratio of proliferating to nonproliferating cells decreased (20) and until the entire culture achieved confluence on day 4 (Fig. $1 C$ ). When stimulated by refeeding (i.e., changing to fresh DMEM/5\% FCS on day 6), cell numbers and total as well as cellular TIP increased significantly $(P<0.001 ;$ Fig. 1$)$. After a single and final cell doubling from day 6 to day $8\left(24 \pm 2\right.$ to $53 \pm 3 \times 10^{6}$ cells), no additional proliferation was noted and no further increase in TIP was observed (Fig. 1). At no time did we observe significant quantities of TIP $\left(>0.17 \mathrm{~T} \alpha_{1}\right.$ peq/ml) in the incubation medium, although total TIP increased $>70$-fold (Fig. 1A). DMEM/5\% FCS without cells contained $0.16 \mathrm{~T} \alpha_{1}$ $\mathrm{peq} / \mathrm{ml}$.

Relationship of TIP to the Proliferative Cycle. There was a correlation between TIP levels and the proliferative cycle. Refeeding cells rendered quiescent by 24-hr incubation in $\mathrm{DMEM} / 0.5 \%$ FCS produced a doubling in cell number that terminated with cellular confluence (Fig. 2). A >3.3-fold increase in cellular TIP occurred within $1 \mathrm{hr}$ of changing the medium to DMEM/5\% FCS $\left(0.04 \pm 0.01\right.$ to $0.14 \pm 0.01 \mathrm{~T} \alpha_{1}$ peq per $10^{6}$ cells; $\left.P<0.001\right)$ with maximum TIP levels observed at $3 \mathrm{hr}$ after refeeding $\left(0.16 \pm 0.02 \mathrm{~T} \alpha_{1}\right.$ peq per $10^{6}$ cells; Fig. 2). A continuous decrease in TIP was observed from the 3 rd hour to the 12th hour after refeeding $(0.16 \pm 0.02$ to $0.07 \pm 0.01 \mathrm{~T} \alpha_{1}$ peq per $10^{6}$ cells; $\left.P<0.001\right)$. From this minimum, TIP increased to $0.14 \pm 0.02 \mathrm{~T} \alpha_{1}$ peq per $10^{6}$ cells at $24 \mathrm{hr}$ after refeeding. This time point $(24 \mathrm{hr})$ is $\approx 3 \mathrm{hr}$ into the following proliferative cycle as determined by the original investigation of this cell line by Quaroni et al. (13).

To correlate changes in TIP levels with the phases of the cellular proliferative cycle a series of experiments was performed parallel to those illustrated in Fig. 2. The time at which maximum $\left[{ }^{3} \mathrm{H}\right]$ thymidine incorporation was observed

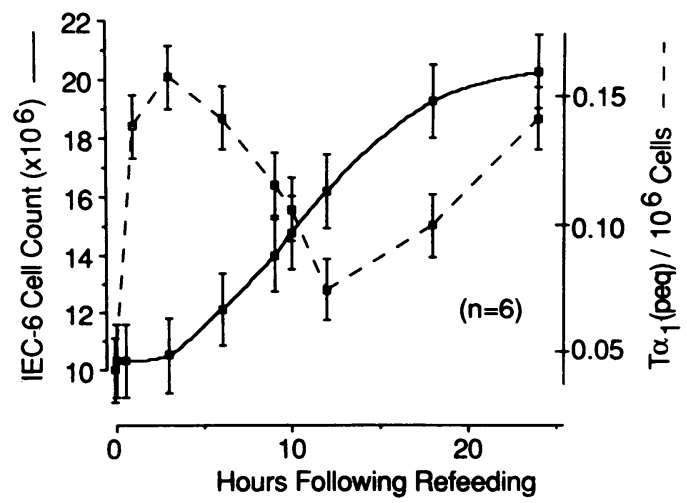

FIG. 2. Relationship of cellular TIP concentration to cell proliferation. IEC-6 cells were seeded into parallel flasks and incubated for $48 \mathrm{hr}$ in DMEM $/ 5 \%$ FCS. The medium was changed to DMEM $/ 0.5 \%$ FCS and incubation continued for $24 \mathrm{hr}$, during which time cell quiescence was achieved. Medium was changed once again (at time 0) to DMEM/5\% FCS (refeeding), which resulted in stimulation of cell proliferation. Flasks were harvested, cells were counted, and supernatants of cell lysates were measured for $\mathrm{T} \alpha_{1}$ peq at the time intervals indicated. All values are means \pm SD. 


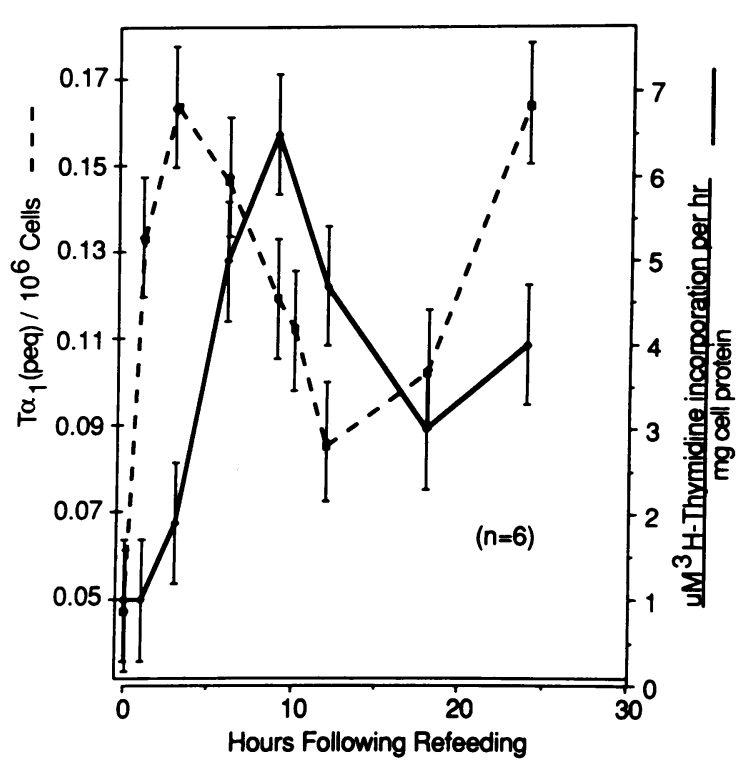

FIG. 3. Correlation of cellular TIP levels with $\left[{ }^{3} \mathrm{H}\right]$ thymidine incorporation by IEC- 6 cells. Parallel flasks were seeded with IEC-6 cells and grown as described in Fig. 2. After refeeding and at $1 \mathrm{hr}$ prior to the time intervals for harvesting indicated in Fig. 2, 50 $\mu \mathrm{l}$ of $\left[{ }^{3} \mathrm{H}\right]$ thymidine $(134 \mu \mathrm{Ci} / \mathrm{ml} ; 1 \mathrm{Ci}=37 \mathrm{GBq}$; New England Nuclear) per $\mathrm{ml}$ of culture medium was added to each flask. The harvested cells were disrupted with $2 \mathrm{ml}$ of $2 \mathrm{M} \mathrm{NaOH}$, passed through sintered glass filters (Whatman), and washed with cold PBS. The filtrates were assayed for $\beta$-emission activity by fluorescence spectrometry. A sample at each time interval was measured for protein concentration by the Bradford microassay (Bio-Rad). Results are expressed as $\mu \mathrm{M}\left[{ }^{3} \mathrm{H}\right]$ thymidine incorporation per $\mathrm{mg}$ of cell protein per $\mathrm{hr}$ (solid line). TIP was measured in supernatants of cell lysates and is expressed as $\mathrm{T} \alpha_{1}$ peq (dashed line). All values are means $\pm \mathrm{SD}$.

was used to define the $S$ phase of the proliferative cycle (Fig. 3). Cell counts $\left(\times 10^{6}\right)$ at selected time points $(t=0 \mathrm{hr}, 10.6$ $\pm 0.8 ; t=18 \mathrm{hr}, 19.6 \pm 0.09 ; t=24 \mathrm{hr}, 20.5 \pm 0.7)$ were used to confirm the presence of a normal proliferative cycle. Maximum cellular TIP levels were seen $3 \mathrm{hr}$ after the proliferative cycle was reestablished by refeeding. Concomitant measurement of $\left[{ }^{3} \mathrm{H}\right]$ thymidine incorporation revealed that maximum incorporation increased from $1.0 \pm 0.5 \mu \mathrm{M}$ $\left[{ }^{3} \mathrm{H}\right]$ thymidine per $\mathrm{mg}$ of cell protein per hr at time 0 to $6.5 \pm$ $0.5 \mu \mathrm{M}\left[{ }^{3} \mathrm{H}\right]$ thymidine per mg of cell protein per $\mathrm{hr}$ at $9 \mathrm{hr}(P$ $<0.001$ ), thereafter declining to a nadir at $18 \mathrm{hr}$ (Fig. 3). Thus, separate and discrete peaks were observed for cellular TIP levels (at $3 \mathrm{hr}$ ) and $\left[{ }^{3} \mathrm{H}\right]$ thymidine incorporation (at $9 \mathrm{hr}$ ).

Influence of the Removal of the Proliferative Stimulus on Cellular TIP Levels. One hour after removal of the proliferative stimulus, cellular TIP levels fell to less than one-half with maximum decline at 6-9 $\mathrm{hr}$ (Fig. 4). Noted during this experiment was the continuation of cellular proliferation during the period of falling cellular TIP. No evidence of the previously described peak TIP level prior to cell proliferation (Fig. 2) was seen during this terminal proliferative cycle.

Immunoelectron Microscopic Localization of TIP in Proliferating Cells. In IEC-6 cells grown in DMEM $/ 5 \%$ FCS, much of the immunogold label was present in the nucleus, predominately over condensed heterochromatin (Fig. 5). Cytoplasmic labeling was present to a lesser degree and in a somewhat more random distribution. This is more clearly observed at higher magnification (Fig. 5 Inset). Control cells treated with antisera to $T \alpha_{1}$ absorbed with immobilized synthetic $T \alpha_{1}$ revealed only background immunogold deposition in the nucleus and cytoplasm.

Characterization of TIP in IEC-6 Cells. HPLC analysis of extracts prepared from IEC- 6 cells and immediately exposed to boiling yielded a major peak that eluted in the position of

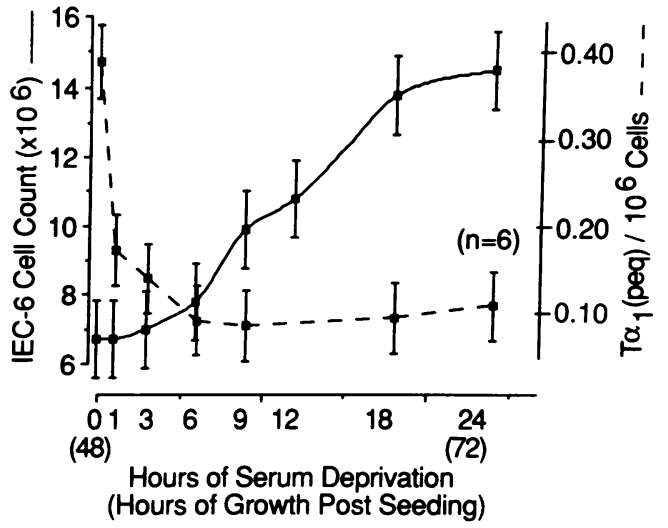

FIG. 4. Influence of the removal of the proliferative stimulus (DMEM/5\% FCS) on IEC-6 cell growth and cellular TIP concentrations. IEC-6 cells were seeded into parallel flasks and incubated in DMEM/5\% FCS. Removal of the proliferative stimulus was achieved by changing the medium to DMEM/0.5\% FCS at $48 \mathrm{hr}$. During the subsequent $24-\mathrm{hr}$ period, cells were harvested and counted. TIP, expressed as T $\alpha_{1}$ peq, was measured in cell lysate supernatants at the time intervals indicated. All values are means \pm SD.

T $\alpha_{1}$ (Fig. 6). Only a trace of immunoreactivity was found in the region corresponding to ProT $\alpha$ (12-13 min). The antibody used would have detected ProT $\alpha$ with reduced $(50 \%)$ sensitivity corresponding to T $\alpha_{1}$ (P.H.N., M.R.E., and A.L.G., unpublished data).

\section{DISCUSSION}

This investigation provides evidence relating thymosin-like peptides to proliferation in rat small intestinal crypt cells. The correlation of cell proliferation in a nonlymphoid cell to increasing cellular content of TIP is in agreement with the earlier observation of an increase in ProT $\alpha$ mRNA content in proliferating NIH 3 T3 fibroblasts as opposed to quiescent NIH 3T3 cells (8). A nuclear site of action for ProT $\alpha$ has been proposed based on structural similarities of this peptide to such nuclear-related agents as nucleoplasmin, cyclin, nucleolin, N038, N1/N2, and several of the high mobility group proteins (7). Evidence for this hypothesis was provided by Watts et al. (22), with the demonstration that ProT $\alpha$ injected into the cytoplasm of oocytes migrated to the nucleus. Conteas et al. (12) have also proposed a nuclear localization. TIP was identified by immunoelectron microscopy on the heterochromatin of the nuclei in crypt cells of the small intestine of the Sprague-Dawley rat and in the IEC-6 cell line with smaller quantities of TIP detected in the cytoplasm of these cells.

The results of the present study provide important insights into the relationship of TIP to cell proliferation. Total TIP increased with active cell proliferation but decreased as the cells reached confluence. Initiation of proliferation by refeeding the cells also produced an increase in total TIP, which ceased as cell proliferation halted (Fig. $1 A$ and $B$ ). There was a tendency for cellular TIP concentrations to reach similar levels after refeeding (Fig. 1C).

During the 9-day cell culture period there was no evidence of significant release of TIP into the incubation medium over each 24-hr period. Thus, the function of TIP would appear to be related to intracellular events. The apparent absence of TIP secretion by this cell line suggests that an endocrine-paracrine role for TIP in cell proliferation is unlikely in this nonlymphoid cell line. A similar conclusion was reached earlier by Goodall et al. (23) and by Eschenfeldt and Berger (8) based on the lack of coding for a signal peptide in the cloned ProT $\alpha$ cDNA. More recently, Eschenfeldt et al. (24) described the localization of ProT $\alpha$ mRNA on free polysomes. 


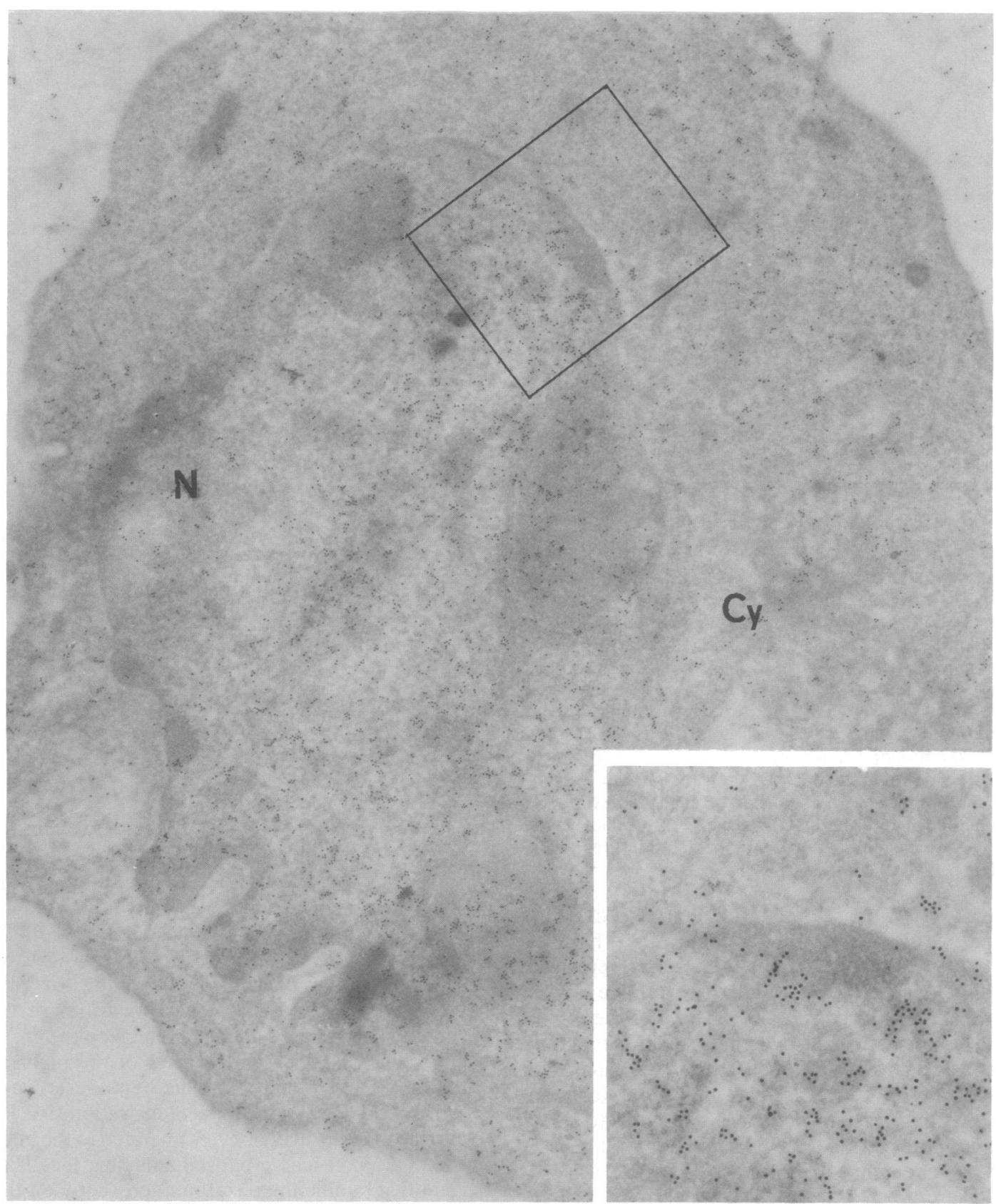

Fig. 5. Ultrastructural immunolocalization of TIP in IEC- 6 cells. IEC- 6 cells were incubated for $48 \mathrm{hr}$ in DMEM/5\% FCS. The medium was changed to fresh DMEM/5\% FCS and, $24 \mathrm{hr}$ later, the cells were harvested, washed twice in PBS, and fixed in periodate/lysine/ paraformaldehyde fixative (21) for $2 \mathrm{hr}$ at room temperature. Postfixation with osmium tetroxide was omitted, and the cells were dehydrated and then embedded by a low denaturation method in Lowicryl K4M polar embedding medium (Polysciences). Ultrathin sections were cut and collected on 300-mesh nickel grids, which were washed in two changes of PBS for 2 min by constant dipping and then transferred directly to a drop of normal goat serum (diluted 1:50 in 1\% bovine serum albumin in PBS) for 5 min. The "blocked" grids were transferred, without washing, to drops of primary antibody (polyvalent rabbit anti-T $\alpha_{1}$ diluted 1:500 in $1 \%$ bovine serum albumin in PBS) and incubated for $2 \mathrm{hr}$ at room temperature in a moist chamber. After three washes with PBS, the sections were blocked again, as described above, and incubated with colloidal gold complexed to the second antibody (goat anti-rabbit IgG; particle diameter, $10 \mathrm{~nm}$; Janssen Pharmaceutica, diluted 1:25 with PBS) for 1 $\mathrm{hr}$. Grids were then washed twice in PBS and twice in deionized water. The reacted sections were contrasted with 5\% aqueous uranyl acetate for 3 min and photographed in a Phillips EM 400 electron microscope. Cytochemical controls, which included (i) omission of anti-T $\alpha_{1}$ antibody, (ii) diluted nonimmune rabbit serum in place of the primary antibody, or (iii) T $\alpha_{1}$ antiserum absorbed with synthetic T $\alpha_{1}$ (Alpha 1 Biomedicals, Foster City, CA) followed by gold-conjugated second antibody, produced essentially negative immunostaining. Gold particles are prominent over condensed chromatin in the nucleus $(\mathrm{N})$. The cytoplasm $(\mathrm{Cy})$ also contains gold particles, but to a lesser extent and more randomly distributed. $(\times 23,400$. $)($ Inset $)$ Boxed area shown at higher magnification. $(\times 53,700$.)

Our present findings suggest that changes in TIP concentration precede cell proliferation and are not so much associated with cellular DNA synthesis (S phase) as with events in the preproliferation $\left(G_{1}\right)$ phase. When cells were allowed to complete a terminal proliferation after DMEM/5\% FCS was replaced with DMEM/0.5\% FCS, cell proliferation continued for one cycle in the presence of falling levels of cellular
TIP (Fig. 4), indicating that there is not only a rapid clearance of TIP from the cell after removal of the proliferative stimulus but, in addition, a probable lack of a requirement for elevated levels of TIP for completion of the cycle of cell division. The role for TIP as suggested by this study implies an association with preproliferative rather than proliferative events.

Correlation of TIP and cellular proliferation (Figs. 1-4) 


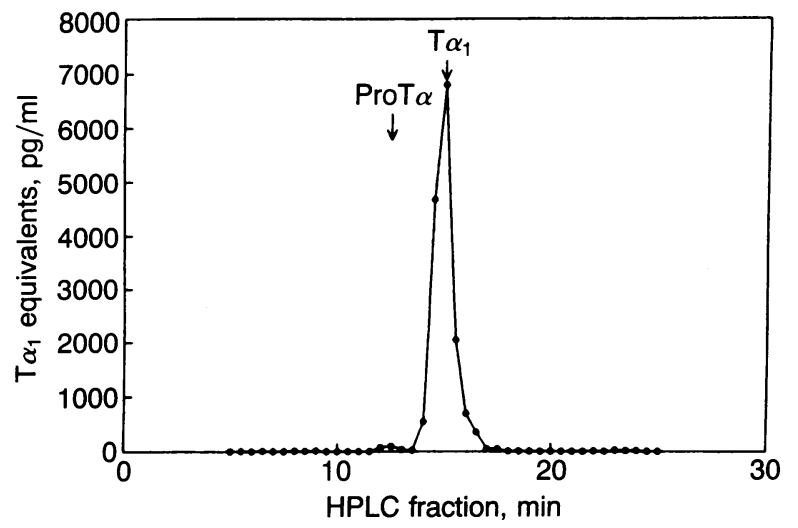

FIG. 6. HPLC analysis. Cell-free supernatants of IEC-6 cells were obtained by immediately exposing cells harvested during the logarithmic phase of growth to $1 \mathrm{ml}$ of boiling PBS (0.1 M; pH 7.0). Boiling was continued for $5 \mathrm{~min}$ and the suspension was centrifuged at $15,000 \times g$ for 30 min and the supernatants were maintained at $-60^{\circ} \mathrm{C}$. Supernatants were desalted and the TIP was concentrated by using a peptide-binding Sep-Pak C18 cartridge (Waters) preconditioned with $5 \mathrm{ml}$ of methanol and then washed with $10 \mathrm{ml}$ of distilled water. The cartridge was primed with $5 \mathrm{ml}$ of $0.0157 \mathrm{M} \mathrm{KH}_{2} \mathrm{PO}_{4} /$ $0.005 \mathrm{M} \mathrm{K}_{2} \mathrm{HPO}_{4}, \mathrm{pH} 6.0$ (Wang A) in distilled water. The sample (200 $\mu$ l diluted 1:10 in PBS) was loaded onto the primed cartridge and washed twice with $2 \mathrm{ml}$ of Wang A, and the eluate was confirmed to be absent of immunoreactive T $\alpha_{1}$ by RIA. The peptide fraction containing TIP was eluted from the column with $2 \mathrm{ml}$ of a $1: 1$ (vol/vol) dilution of Wang A and $50 \%$ acetonitrile in Wang A. All samples were frozen at $-80^{\circ} \mathrm{C}$ and lyophilized overnight in a FlexiDry Systems Lyophilizer (Stone Ridge, NY) and then reconstituted with prefiltered distilled water prior to HPLC sizing analysis. Aliquots were injected onto a Spherogel TSK 2000 HPLC sizing column $(7.5 \times 300 \mathrm{~mm})$ installed in a Beckman 160 HPLC apparatus. Isocratic elution was performed with $0.01 \mathrm{M}$ sodium acetate $/ 0.15 \mathrm{M}$ $\mathrm{NaCl}$ buffer, $\mathrm{pH} 6.0$, at a flow rate of $0.6 \mathrm{ml} / \mathrm{min}$. Fractions were collected at 0.5 -min intervals. Peptide elution was recorded by UV detection with optical density at $214 \mathrm{~nm}$. Synthetic T $\alpha_{1}$ and native ProT $\alpha$ (2) were chromatographed under the same conditions as standards to verify retention times of $12 \min$ for ProT $\alpha$ and $14.5 \mathrm{~min}$ for $\mathrm{T} \alpha_{1}$.

with the immunoelectron microscopic analysis (Fig. 5) suggests that TIP may function to regulate proliferation at the nuclear level. The data presented here further indicate that TIP may be rapidly synthesized and associated anatomically with the chromatin material of the nucleus and temporally with events just preceding cellular proliferation.

Finally, the observations presented here underscore the difficulties in defining the relative importance of peptide fragments such as $\mathrm{T} \alpha_{1}$ versus its precursor, ProT $\alpha$, in biological functions. Although the TIP present in the IEC-6 cells has not been positively identified, the behavior of the extracted TIP in HPLC corresponds to that of T $\alpha_{1}$ rather than ProT $\alpha$. However, the extraction procedures used would not have precluded proteolytic degradation of native ProT $\alpha$. The possibility also remains that ProT $\alpha$ is processed to smaller fragments in the nucleus. Formation of $\mathrm{T} \alpha_{1}$ would have resulted in the loss of the major nuclear targeting signal, which is located near the $\mathrm{C}$ terminus of ProT $\alpha(7,22)$. However, a second potential nuclear targeting signal, LysLys-Glu-Lys at residues 17-20, would be retained in T $\alpha_{1}(1)$.
In any event, the results obtained in the HPLC studies confirm that a peptide related to ProT $\alpha$ was measured in the cell proliferation studies.

The observations in this study support the hypothesis that ProT $\alpha$ and/or $\mathrm{T} \alpha_{1}$ may play an important intracellular and intranuclear role linked to cell proliferation.

We thank Ms. Jia $\mathrm{Li}$ and Dr. John R. Haapaniemi for expert technical assistance. This work was supported in part by Grant HL 32870 (K.C.P.) from the National Heart, Lung and Blood Institute; Grants CA43280 (G.D.L.), CA49274 (A.L.G.), AG00541, and AI22901 (B.L.H.) from the National Institutes of Health; and Grant FD-R-000096 (M.G.M.) from the Food and Drug Administration. C.P. is the recipient of a Rockefeller Foundation Biotechnology Career Fellowship.

1. Goldstein, A. L., Low, T. L. K., McAdoo, M., McClure, J., Thurman, G. R., Rossio, J., Lai, C.-Y., Chand, D., Wang, S.-S., Harvey, C., Ramel, A. H. \& Meienhofer, J. (1977) Proc. Natl. Acad. Sci. USA 74, 725-729.

2. Haritos, A. A., Goodall, G. J. \& Horecker, B. L. (1984) Proc. Natl. Acad. Sci. USA 81, 1008-1011.

3. Hirokowa, K., McClure, J. E. \& Goldstein, A. L. (1982) Thymus 4, 19-29.

4. Piltch, A., Naylor, P. \& Hayashi, J. (1988) In Vitro 24, 289-293.

5. Franco, F. J., Diaz, C., Barcia, M., Arias, P., Gomez-Marquez, J., Soriano, F., Mendez, E. \& Freire, M. (1989) Immunology 67, 263-268.

6. Haritos, A. A., Tsolas, O. \& Horecker, B. L. (1984) Proc. Natl. Acad. Sci. USA 81, 1391-1393.

7. Gomez-Marquez, J. \& Segade, F. (1988) FEBS Lett. 226, 217-219.

8. Eschenfeldt, W. H. \& Berger, S. L. (1986) Proc. Natl. Acad. Sci. USA 83, 9403-9407.

9. Makarova, T., Grebenshikov, N., Egorov, C., Vartapetian, A. \& Bogdanov, A. (1989) FEBS Lett. 257, 247-250.

10. Gomez-Marquez, J., Segade, F., Dosil, M., Pichel, J. G., Bustelo, X. R. \& Freire, M. (1989) J. Biol. Chem. 264, 84518454.

11. Oates, K. K., McGinty, M. C. \& Turner, T. (1988) Med. Sci. Res. 16, 907-909.

12. Conteas, C., Su, Y.-L., Palmer, K. \& Mutchnick, M. (1989) FASEB J. 3, A1151.

13. Quaroni, A., Wands, J., Trelstad, R. L. \& Isselbacher, K. J. (1979) J. Cell Biol. 80, 248-265.

14. Conteas, C. N. \& Majumdar, A. P. N. (1987) Proc. Soc. Exp. Biol. Med. 184, 307-311.

15. Kurokowa, M., Lynn, K. \& Podolsky, D. K. (1987) Biochem. Biophys. Res. Commun. 142, 775-782.

16. Weller, F. E., Mutchnick, M. G., Keren, D. F., Goldstein, A. L. \& Naylor, P. H. (1985) J. Immunol. Methods 80, 45-53.

17. McClure, J. E., Lameris, N., Wara, D. W. \& Goldstein, A. L. (1982) J. Immunol. 128, 368-375.

18. Panneerselvam, C., Haritos, A. A., Caldarella, J. \& Horecker, B. L. (1987) Proc. Natl. Acad. Sci. USA 84, 4465-4469.

19. Wada, S., Naylor, P. H., Naylor, C. W. \& Goldstein, A. L. (1988) Int. J. Immunopharmacol. 10, 795-801.

20. Quaroni, A. \& May, R. J. (1980) Methods Cell Biol. 21B, 403-427.

21. McLean, I. W. \& Nakane, P. K. (1974) J. Histochem. Cytochem. 22, 1077-1083.

22. Watts, J. D., Cary, P. D. \& Crane-Robinson, C. (1989) FEBS Lett. 245, 17-20.

23. Goodall, E. J., Dominquez, F. \& Horecker, B. L. (1986) Proc. Natl. Acad. Sci. USA 83, 8926-8928.

24. Eschenfeldt, W. H., Manrow, R. E., Krug, M. S. \& Berger, S. L. (1989) J. Biol. Chem. 264, 7546-7555. 